BŁAŻEJ PRZYBYLSKI

Wydział Nauk Pedagogiczych

Akademia Pedagogiki Specjalnej

im. Marii Grzegorzewskiej w Warszawie

ORCID ID: https://orcid.org/oooo-0oo2-0663-8692
Forum Pedagogiczne

$9(2019) 2$, cz. 1

Wpłynęło: 29.01.2019 Zatwierdzono do druku: 26.06.2019 DOI: $10.21697 / \mathrm{fp} \cdot 2019 \cdot 2.16$

\title{
„MEGATRENDY” WE WSPÓŁCZESNYM ŚWIECIE. PERSPEKTYWA EUROPEJSKA
}

Streszczenie: W artykule podjęto tematykę „megatrendów”, czyli kluczowych tendencji o zasięgu globalnym. Autor dokonuje krótkiej charakterystyki pojęcia, które na przestrzeni lat zmieniało swoje znaczenie oraz prezentuje najważniejsze jego cechy. Podkreśla przy tym kontrowersje związane z nazywaniem konkretnych zjawisk mianem „megatrendy”. Identyfikacja sił, zmieniających kierunek rozwoju świata stanowi jedno z podstawowych narzędzi prognozowania przyszłości. Oddziałują one nie tylko na życie całych społeczeństw, lecz także stanowią istotny czynnik w projektowaniu indywidualnych biografii. $\mathrm{W}$ tekście, na podstawie raportów badawczych i opracowań naukowych, wymieniono najważniejsze tendencje występujące we współczesnym świecie. Wybrane z nich zostały omówione i podparte danymi statystycznymi. Autor przygląda się im z perspektywy europejskiej, zarysowując główne zadania stojące przed światem zachodu. Z kolei w kontekście pedagogicznym akcentuje znaczenie uczenia się przez całe życie, któremu przypada kluczowe znaczenie w rozwiązywaniu globalnych oraz edukacyjnych problemów i wyzwań.

Słowa kluczowe: „megatrendy”; globalizacja; urbanizacja; demografia; edukacja; uczenie się przez całe życie.

\section{Wprowadzenie}

Diagnoza obecnej kondycji świata nie wystarczy, aby myśleć spokojnie o nadchodzącej przyszłości. Badacze, politycy, naukowcy i zwykli obserwatorzy rzeczywistości, spoglądając na kształt współczesnego świata, na zachodzące w nim procesy, tworzą wizje, prognozy i przewidywania dotyczące przyszłości. Jednym z kluczowych zadań stojących przed globalną społecznością jest dostrzeżenie i właściwa interpretacja aktualnych tendencji, które nie tylko przyczynią się do istotnych zmian w przyszłości, lecz także już dziś powodują gwałtowne przeobrażenia o nieuniknionych konsekwencjach dla życia miliardów obywateli tego świata. Rozpoznanie zjawisk znaczących z ogólnospołecznego punktu widzenia, 
określanych mianem „megatrendy”, pozwala na zdefiniowanie najbardziej istotnych tendencji o charakterze globalnym. Wiedza o nich pozwala zaplanować odpowiednią strategię działania i rokuje szanse na sprostanie ambitnym wyzwaniom. Jednym z kluczowych zadań, stojących przed globalnym społeczeństwem, jest zatem identyfikacja trendów, umożliwiająca projektowanie kierunków rozwoju przyszłego świata. Nie mniej istotne jest rozpoznanie owych trendów w kontekście pedagogicznym.

Świadomość zachodzących zmian i wiedza o ich następstwach stanowią niewątpliwie impuls do rozważnego namysłu nad zastaną rzeczywistością, pożądanymi kierunkami zmian i celami edukacji, której najwyższym celem jest dobro człowieka, gdziekolwiek on żyje, pracuje i tworzy. W edukacji właśnie pokłada się nadzieję na budowanie zaangażowania, odpowiedzialności i solidarności między mieszkańcami globu, gdyż - jak wskazują przedstawione poniżej „megatrendy” - realizacja projektu, jakim jest świat przyjazny człowiekowi, stanie się możliwa dopiero wówczas, gdy wszyscy mieszkańcy Ziemi zrozumieją, że jest ona ich wspólną wartością i jako taka wymaga ogólnoświatowej troski, wyrażającej się m.in. refleksyjnym i racjonalnym działaniem jednostek i społeczeństw.

\section{„Megatrendy”. Ustalenia terminologiczne}

Termin „megatrendy” zaczęto stosować w celu identyfikacji zasadniczych, najbardziej kluczowych tendencji rozwojowych. Można go zdefiniować jako „ekonomiczne, społeczne, polityczne i kulturowe zjawiska powstałe w procesie rozwoju cywilizacyjnego człowieczeństwa, mające różnorakie uwarunkowania, oddziałujące - jako stałe tendencje - na ludzkość (Muszyński 2001, s. 19). Prandecki (2012, s. 79) dodaje, że „zjawiska te powinny charakteryzować się dużym prawdopodobieństwem wystąpienia, lecz jednocześnie dopuszcza się możliwość ich korekty w wyniku działania innych podobnych sił”. Do „megatrendów” możemy zaliczyć zatem m.in.:

a. procesy transformacyjne, dokonujące się w społeczeństwach (Naisbitt 1997);

b. znaczące zjawiska, które mają bliżej określone kierunki zmian (Borodako 2009);

c. siły, które zmieniają świat (Horx 2007);

d. tendencje cywilizacyjne (Pajestka 1994).

Niektórzy naukowcy, publicyści, a także międzynarodowe instytucje stawiają znak równości między „globalnymi wyzwaniami” a „megatrendami”. Wydaje się jednak, że „globalne wyzwanie” to bardziej złożony termin. Oprócz „megatrendów” lub inaczej - trendów o globalnym zasięgu, w obręb globalnego wyzwania wchodzą również globalne problemy, już zidentyfikowane oraz te dotychczas „nieznane, niewiadome”, zachodzące we współczesności, aczkolwiek nadal niesprecyzowane (Cuhls i in. 2012, s. 233). 
W początkowym okresie termin „megatrendy” służył do opisania tendencji o zasięgu krajowym. Następnie zaczęto go utożsamiać ze zmianami o charakterze globalnym. Współcześnie stosowanie tego terminu rozszerza się najczęściej do poziomu międzynarodowego, ogólnoświatowego. Niemniej, posługując się nim, nie odnosimy się wyłącznie do tych trendów, które mają charakter globalny i dotyczą wszystkich bez wyjątku kultur, kręgów cywilizacyjnych czy państw narodowych. Trudno znaleźć jakiekolwiek procesy czy fenomeny, które dotykałyby cały glob. Przykładowo, gdy mowa o starzeniu się społeczeństw, jako tendencji globalnej, należy pamiętać o tym, że problem ten nie dotyczy wszystkich współczesnych społeczeństw; w niektórych regionach świata społeczeństwa są młode. Myśląc o „megatrendach” można odnosić się też do konkretnego kontynentu, kręgu cywilizacyjnego czy choćby regionu (np. „megatrendy województwa podlaskiego”). Jak widać, termin „megatrendy” może dotyczyć różnych poziomów i skali, nie tylko tej globalnej.

Na ogół jednak podkreśla się ich ponadlokalny charakter. Definicja terminu, sformułowana przez jego propagatora, amerykańskiego futurologa Johna Naisbitta (1997), pozwala skonstatować, że „megatrendy” to nic innego jak wielkie prądy powodujące zmiany. Biorą one swój początek w obecnym czasie, w teraźniejszości. Poprzez nawarstwianie się zmieniają sukcesywnie systemy wartości i w konsekwencji kształt ludzkiego życia w nadchodzącym czasie. Wpływają one na dzieje ludzkości, wyznaczając kierunki, w których w przyszłości będzie podążał świat. Jednocześnie pozwalają prognozować przyszłe zmiany, przystosowywać się do nich, zapobiegać im lub ograniczać ich oddziaływanie.

„Megatrendy” mogą mieć dwojaki charakter: pozytywny lub negatywny. Jakim przymiotnikiem zostaną opatrzone, zależy od oceny ich wpływu na rzeczywistość społeczną (Komitet Prognoz..., 1995, s. 49). Trendy pozytywne to zazwyczaj te, którym przypisuje się potencjał rozwojowy, umożliwiający wzrost ogólnego dobrobytu i podniesienie szeroko rozumianej „jakości” życia. Pozytywne trendy stanowią nadzieję na przezwyciężenie dotychczasowych bolączek świata, uniknięcie potencjalnych niebezpieczeństw i realizację długofalowych ogólnospołecznych celów. Z kolei trendy o oddziaływaniu negatywnym postrzegane są jako zagrożenia dla stabilizacji i porządku społecznego. Z pomocą przychodzą różnorodne strategie, wskazujące m.in na skuteczne narzędzia i środki, które mogą przeciwdziałać zagrożeniom. Pokładana jest w nich nadzieja na zapobieżenie niepożądanym skutkom lub złagodzenie niepożądanych tendencji.

Określenie konkretnego trendu mianem „megatrendu” oraz uznanie go za skutek lub przyczynę pojawiających się innych tendencji o zasięgu globalnym jest zabiegiem nacechowanym dużą dozą subiektywizmu (Sulmicka 2016 s. 13). We współczesnym zglobalizowanym świecie zdaje się być oczywistością, że wszelkie ważne procesy i zjawiska stanowią następstwo innych tendencji i mogą równocześnie być przyczyną i skutkiem powstawania kolejnych trendów. (Przykładowo, „terroryzm” może funkcjonować w naukowych opracowaniach i raportach badawczych jako 
trend, jednak równocześnie może być postrzegany jako zjawisko wygenerowane przez inne „megatrendy”, np. rosnące nierówności czy amerykańską dominację; może też być uznany za przyczynę np. odchodzenia od religii). Subiektywizm towarzyszy również określaniu mianem globalnych trendów grupy wydarzeń czy występujących zjawisk i procesów. Arbitralność dotyczy zarówno szacowania ich siły sprawczej i zakresu występowania, jak i prawdopodobieństwa przyczynienia się do istotnych zmian w przyszłości. Jako przykład tego można podać jedno z głośniejszych proroctw odnoszące się do triumfu systemów demokratycznych nad autorytarnymi oraz transformacji systemów gospodarczych. Na początku lat 90. XX wieku istniał pełen konsens co do tych dwóch „megatrendów” - rozpowszechniania się systemu wolnorynkowego oraz demokratycznego. Czy aby na pewno przewidywania socjologów, ekonomistów i polityków się spełniły? Czy jednak ta tendencja nie została mylnie zidentyfikowana? Dziś sytuacja rozwija się raczej w przeciwnym kierunku. Można mnożyć pytania o istotę, tendencje rozwoju czy przyczyny i skutki wspomnianych trendów. Niewątpliwie jednak, jak wskazują choćby dwa wymienione powyżej przykłady, mamy do czynienia z dużą dowolnością i uznaniowością w identyfikowaniu i rozpoznawaniu trendów o charakterze globalnym.

Przede wszystkim „megatrendy” oddziałują na całe gospodarki, ale również na konkretne obszary polityki państwowej (np. bezpieczeństwo, sprawy socjalne czy edukacyjne), aktywności człowieka (np. turystyka) czy też sferę duchowości (religijność). Co więcej, mają znaczenie zarówno na poziomie państwowym czy funkcjonowania przedsiębiorstw, jak i na poziomie jednostkowym, stanowiąc istotny czynnik projektowania indywidualnej ścieżki życiowej. Upraszczając, można powiedzieć, że to właśnie „megatrendy” podpowiadają, co należy studiować, żeby być bogatym i szczęśliwym, gdzie i w co lokować własny kapitał, jakich uczyć się języków obcych, aby być lepiej ustawionym, jaki sport trenować i czym się zajmować w czasie wolnym od pracy. „Megatrendy” wyznaczają przyszłość jednostek i całych społeczeństw.

Niejako w opozycji do „megatrendów” pojawiają się też „mikrotrendy” (Penn, Zalesne 2007). Nie należy zapomnieć o tym, że współczesny świat kształtują nie tylko potężne, ogólnoświatowe tendencje, lecz także decyzje, wybory, aspiracje i działania względnie małych środowisk. Aby zrozumieć współczesność, nie należy ograniczyć się do poszukania globalnych i uniwersalnych tendencji świata, lecz przyjrzeć się aktywnościom jednostek i małych grup. To ich potrzeby, dążenia i pragnienia znajdują się w centrum uwagi przedsiębiorców, strategów czy globalnych firm, starających się zaspokoić oczekiwania konsumentów i obywateli. Codzienne decyzje i wybory, podejmowane przez mieszkańców miast i wsi, lokalne wspólnoty, subkultury czy grupy młodzieżowe współkształtują dzisiejszy świat. 


\section{Wybrane „megatrendy” - przyczynek do dyskusji. Perspektywa europejska}

W poniższym fragmencie zaprezentuję kilka wybranych „trendów”, a właściwie grup trendów uważanych za najbardziej kluczowe dla przyszłości świata. Na najważniejsze „megatrendy” we współczesnym świecie wskazują liczne raporty badawcze i opracowania (CSIRO 2012; Ernst, Young 2015; Komisja Europejska 2012). Wymieniają one od kilku do nawet kilkudziesięciu „megatrendów”.

Janusz Mariański (2016, s. 19) zauważa, że „megatrendy” „odnoszą się przede wszystkim do gospodarki". Wielu myślicieli podkreśla, że tym najbardziej podstawowym, najsilniejszym trendem, wyznaczającym inne tendencje jest obecnie globalizacja, której znaczenie wykracza daleko poza kwestie ekonomiczne. Pojęcie to w ciągu ostatnich kilkudziesięciu lat robi zawrotną karierę. Słowo „Globalizacja jest na ustach wszystkich. Słowo na czasie, które szybko zmienia się w slogan, w magiczną formułę, w hasło otwierające bramy wszystkich tajemnic teraźniejszości i przyszłości" (Bauman 2000, s. 5). Globalizacja jako zjawisko o charakterze wszechobecnym i wszechogarniającym obrazuje diametralne różnice w ocenie skutków „megatrendów”. Przez jednych tendencja ta przyjmowana jest pozytywnie, wręcz entuzjastycznie, jako niosąca ze sobą przede wszystkim korzyści. Inni zaś widzą w niej zagrożenie dla bezpieczeństwa, porządku i stabilizacji światowej. Wszyscy zgodni są jednak co do tego, że stanowi ona „nieunikniony los świata, a także [...] nieodwracalny proces, który dotyczy każdego $\mathrm{z}$ nas $\mathrm{w}$ takim samym stopniu i w ten sam sposób" (Bauman 2000, s. 5). Jej zwolennicy wskazują na to, że stanowi ona „ideologię wzrostu” (Zacher 2003, s. 216). Sceptycyzm przeciwników globalizacji oddają słowa Tadeusza Kowalika (2000, s. 343): „proces globalizacji gospodarki światowej uchodzi za największe zagrożenie dla utrzymania różnorodności systemów społeczno-ekonomicznych. [...] nieodległa jest chwila, gdy swoistości systemowe znikną na rzecz mniej lub bardziej jednolitej prywatno-kapitalistycznej gospodarki rynkowej na świecie". W globalizacji upatrują jej przeciwnicy przede wszystkim narzędzia amerykańskiej dominacji, źródła rosnących nierówności i konfliktów społecznych, zagrożeń związanych z eksploatowaniem środowiska naturalnego oraz filozofii traktowania zysku ponad człowieka.

Jednym z najczęściej wskazywanych procesów w obszarze szeroko rozumianej ekonomii jest przenoszenie centrum gospodarczego, dotychczas utożsamianego z krajami należącymi do tzw. kręgu zachodnioeuropejskiego (głównie UE i Ameryka Północna), w stronę nowych państw aspirujących do miana potęg gospodarczych, leżących głównie na kontynencie azjatyckim. Według prognoz licznych ekonomistów, obraz gospodarczy świata za 10 lat będzie znacznie odbiegał

1 Tabela umieszczona w artykule prezentuje zestawienie najważniejszych rozpoznanych trendów, z uwzględnieniem obszarów, w których występują, z zastrzeżeniem, że części z nich nie można jednoznacznie zaklasyfikować do konkretnego obszaru, a zdecydowana większość ma wpływ na inne pojawiające się w świecie tendencje. 
od współczesnego porządku świata i nieodwołalnie nastąpi „zmiana światowej architektury ekonomicznej" (Sulmicka 2016, s. 14).

Problematyka nierówności społecznych, stanowiąca od lat przedmiot zainteresowania różnych dyscyplin naukowych, jest uznawana za jedną z głównych tendencji współczesności. Jak zauważa jeden z najpopularniejszych ekonomistów naszych czasów Joseph E. Stiglitz (2015, s. 23), „nierówności, zwłaszcza te pogłębiające się przez szybkie bogacenie się najbogatszych, budzą coraz większe zaniepokojenie niemal na całym świecie - spowolnienie gospodarcze prawie wszędzie pogorszyło sytuację ludzi, głównie średnio zamożnych i ubogich”. Renomowany ekonomista Thomas Piketty (2015) pisze wręcz o „hiperkoncentracji majątkowej”.

Kolejnym, powszechnie dostrzeganym „megatrendem”, jest urbanizacja. Szacunki mówią o tym, że w 1800 roku mieszkańcy miast stanowili zaledwie dwa proc. ogólnej liczby populacji, w 1950 roku - ok. 30 proc., a w 2018 roku już ponad połowa mieszkańców globu zamieszkiwała miasta. Do 2060 roku odsetek ludności mieszkającej w miastach ma wzrosnąć do 68 proc.. W Europie poziom urbanizacji wynosi już dziś 74 proc. (ONZ 2018). Ogólna tendencja wzrostowa nie oznacza jednakowego tempa wzrostu na wszystkich kontynentach. Najszybciej liczba osób zamieszkujących miasta będzie rosła w Azji i Afryce Subsaharyjskiej. W Europie do 2050 roku ok. 80 proc. mieszkańców będzie zamieszkiwało miasta (BBVA). Szybka urbanizacja niesie ze sobą znaczące implikacje w wielu dziedzinach życia, m.in. w biznesie, edukacji, ochronie środowiska. Rosnąca populacja miast stanowi wyzwanie: trzeba będzie zmierzyć się m.in. z koniecznością usprawniania i ulepszania transportu publicznego, rozbudową sieci dróg, budowaniem nowych mostów i portów, zwiększeniem liczy placówek opiekuńczych i edukacyjnych, dostarczaniem większej ilości prądu i wody, modernizacją kanalizacji miejskiej i budową oczyszczalni ścieków. To tylko nieliczne z wyzwań stojących przed społeczeństwem, które musi przygotować się na drastyczne zmiany w strukturze zamieszkania.

Inna, często i skwapliwie poruszana kwestia, dotyczy obszaru demografii, która jest jednym z podstawowych narzędzi prognozowania społecznego. Rozpoznanie trendów demograficznych stanowi główny element realizowania skutecznej polityki ekonomicznej, społecznej i edukacyjnej. Zmiany demograficzne, coraz bardziej widoczne nawet dla przeciętnego obserwatora podróżującego po Europie Zachodniej, stanowią przedmiot debat środowisk zatroskanych o przyszłość Starego Kontynentu. „Siwiejąca Europa, jeszcze dość młoda Azja i Afryka, starzejące się Ameryka Północna i Południowa - to obraz demograficzny przyszłości” (Czerniawska 2002, s. 15). Rozbrzmiewają głosy alarmujące, że czeka nas „demograficzne samobójstwo”, którego przyczyny leżą m.in. w spadku płodności, spadku współczynnika urodzeń czy zwiększeniu długości życia. Zgodnie z prognozami, w ciągu następnych lat na świecie przybędzie znacznie ponad miliard ludzi, zaś w 2029 roku całkowita liczba populacji wyniesie 8,3 miliarda. Mimo zwiększającej się liczby ludności na świecie, Europa będzie musiała zmierzyć się z tendencją 
odwrotną, z redukcją populacji i gwałtownym procesem starzenia się. Jeszcze do 2025 roku liczba mieszkańców krajów przynależących do UE będzie minimalnie rosła, ale w kolejnych latach Europejczycy odnotują spadek (przez 20 lat ubędzie 36 mln ludzi). W 2050 roku UE ma liczyć ok. 470 milionów obywateli; jednocześnie ponad 10 proc. mieszkańców Unii Europejskiej przekroczy 8o rok życia, a liczba osób powyżej 65 roku życia zwiększy się prawie dwukrotnie w stosunku do stanu obecnego. Zarazem udział ludzi w wieku 15-64 lata spadnie o 20 proc. Z jednej strony wydłużenie się średniej długości życia obywateli Europy uznaje się za sukces i świadectwo zarówno postępu technicznego i medycznego, jak i efekt promocji zdrowego stylu życia. Z drugiej strony, zmiana ta będzie zapewne skutkować wieloma nowymi problemami: brakiem siły roboczej, być może koniecznością masowej migracji czy też narastającymi trudnościami w sferze świadczeń społecznych. Obecnie stosunek osób znajdujących się w wieku produkcyjnym do populacji w wieku poprodukcyjnym wynosi 4:1, do 2050 roku zmniejszy się do proporcji 2:1 (Komisja Europejska 2012, s. 83). Zmniejszająca i starzejąca się populacja mieszkańców starej Europy stanowi jedno z głównych wyzwań, przed którymi stoją rządy państw narodowych i organizacji europejskich.

Nie sposób przejść obojętnie nad zmianami w sferze sacrum. Badacz religijności, Janusz Mariański, wskazuje na co najmniej kilka trendów w odniesieniu do religii: sekularyzację i desekularyzację, pluralizację i indywidualizację religijności oraz nową duchowość. Ten sam autor zaznacza, że to właśnie „Europie przysługuje «status szczególny», bowiem na jej terytorium procesy sekularyzacyjne są najbardziej widoczne i przejawiają się w osłabieniu mocy integracyjnej religii, w spadku członkostwa w Kościołach chrześcijańskich, w rosnącej obojętności religijnej i swoistej płynności wiary. Wzrasta liczba osób określających się jako niereligijne, a nawet jako ateiści” (Mariański 2016, s. 76). Najnowsze dane (Benedykt XVI, Centre for Religion and Society, 2018) pokazują silnie zróżnicowanie w obszarze religijności wśród młodych Europejczyków (16-29 lat); generalnie jednak trend ogólnoeuropejski charakteryzuje się spójnością: odsetek osób regularnie uczęszczających do Kościoła oraz deklarujących się jako osoby wierzące spada. Przynależność do religii chrześcijańskiej deklaruje 82 proc. młodych Polaków, 71 proc. Litwinów i 59 proc. Irlandczyków i Słoweńców. Na drugim biegunie znajduje się młodzież z Czech (90 proc. deklaruje się jako osoby nieprzynależące do żadnej religii), Estonii i Szwecji (odpowiednio 80 proc. i 75 proc.). Ponad 70 proc. Czechów i ok. 60 proc. Hiszpanów, Holendrów, Brytyjczyków nigdy nie uczestniczy w praktykach religijnych. Jeszcze większa część młodzieży deklaruje, że nigdy się nie modli. Także wśród samych katolików spada odsetek osób regularnie uczestniczących we mszy świętej. Najrzadziej biorą w niej udział młodzi dorośli deklarujący się jako katolicy z Belgii (2 proc.), Węgier i Austrii (po 3 proc.); najczęściej zaś Polacy (47 proc.), Portugalczycy (27 proc.) i Czesi (24 proc.). Polska młodzież, jak pokazują badania, na tle pozostałych Europejczyków najsilniej identyfikuje się z Kościołem Katolickim. 
W przestrzeni publicznej sporo miejsca poświęca się również „megatrendom” środowiskowym. Dyskurs środowiskowy lokuje się przeważnie w negatywnym kontekście ogólnych tendencji prowadzących do szeregu niebotycznych zagrożeń. Kwestią, w ostatnim czasie medialnie najgorętszą, jest tzw. globalne ocieplenie. Gdyby potwierdziły się najbardziej pesymistyczne proroctwa, skutki będą katastrofalne (np. podniesienie się poziomu wód oceanicznych i zalanie zamieszkałych przez ludzi lądów czy rozpowszechnienie się chorób zakaźnych) (np. Giddens 2012, s. 647). Specjaliści biją na alarm: „równolegle do zagrożeń związanych z ociepleniem klimatu, występują inne równie niepokojące tendencje (Mayor 2001, s. 173). W tym miejscu otwiera się bogata lista zagrożeń wynikających z beztroskiej i krótkowzrocznej działalności człowieka w świecie przyrody: pogorszenie się jakości gleb i czystości powietrza, zanieczyszczenie wód, katastrofy przyrodnicze, prowadzące do pojawienia się nowej kategorii „uchodźców ekologicznych”, kurczenie się zasobów naturalnych z jednoczesnym przyrostem ogólnej liczby ludności na świecie, zanik pewnych gatunków zwierząt i roślin szczególnie na północy Europy. Warto też podkreślić, że „wszelkie kwestie ekologiczne są zawsze kwestiami natury społecznej i kulturowej, ponieważ dotyczą zawsze warunków egzystencji ludzkich wspólnot" (Walzer 2016, s. 157). To, co dziś wydaje się odległą wizją i kwestią w większym stopniu natury technicznej, w rzeczywistości będzie silnie oddziaływać na życie, jeśli jeszcze nie w życiu współczesnych pokoleń, to zapewne następnych.

„Megatrendy” nie omijają też edukacji. „Polityki oświatowe konfrontowane są przez dwujednię procesów pozornie sobie przeciwstawnych: rynek światowy vs. oświata w hierarchii ekonomii; suwerenność polityczna resortu edukacji $v s$. jej umiędzynarodowienie, globalizacja; heterarchiczne praktyki międzynarodowe w edukacji vs. hierarchiczne praktyki oświatowe w kraju; globalne współzarządzanie $v s$. współzarządzanie korporacyjne; partnerstwo publiczno-prywatne $v s$. etatyzm oświatowy; udział w edukacji społeczeństwa obywatelskiego $v s$. hegemonia władz państwowych" (Śliwerski 2018, s. 17). Do najważniejszych trendów zachodzących w Europie zalicza się:

a. upowszechnienie szkolnictwa wyższego;

b. wydłużenie obowiązkowej edukacji szkolnej, m.in. przez obniżanie wieku rozpoczęcia obowiązkowej edukacji;

c. wzrost autonomii szkół;

d. upowszechnienie edukacji przedszkolnej (w tym szczególnie bezpłatnej);

e. wzrost odsetka studiujących kobiet (za: Eurydice 2012);

f. wzrost zainteresowania edukacją małego dziecka (Nowakowska-Siuta 2015, s. 45).

Na marginesie skonstatuję, że przy pobieżnym nawet przeglądzie trendów i tendencji europejskich w obszarze edukacji widać, że nie wszystkie kraje należące do Unii Europejskiej poddają się im w równym stopniu. Niektóre z rozwiązań popularnych i forsowanych przez polityki państwowe w części krajów spotykają 
się z różnych powodów (np. ideologicznych lub finansowych) z ignorancją i odrzuceniem w innych państwach, przyjmujących w zamian rozwiązania idące jednoznacznie w odwrotnym kierunku.

Tabela 1. Przykładowe „megatrendy”

\begin{tabular}{|c|c|}
\hline "Megatrendy” & Przykłady \\
\hline Gospodarcze & $\begin{array}{l}\text { Globalne siły kapitałowe - rosnące znaczenie korporacji ponad- } \\
\text { narodowych, rynek globalny, narastające nierówności, fetyszy- } \\
\text { zowanie wzrostu PKB gospodarka informacyjna, gospodarka } \\
\text { oparta na wiedzy, inteligentna gospodarka smart economy, } \\
\text { przesuwanie się centrum gospodarki światowej; }\end{array}$ \\
\hline Demograficzne & Starzenie się społeczeństw, urbanizacja; \\
\hline Społeczne & $\begin{array}{l}\text { Przemiana wartości, indywidualizacja rozumiana jako uwalnia- } \\
\text { nie się jednostek spod wpływu tradycyjnych instytucji i struktur, } \\
\text { nowe style i formy życia, zmiany w podziale obowiązków w ro- } \\
\text { dzinie, równouprawnienie płci, wzrost znaczenia kobiet, rozwój } \\
\text { prekariatu, ekspansja klasy średniej, wzrost znaczenia wirtual- } \\
\text { nych wspólnot, wycofywanie się ludzi z życia publicznego, wzrost } \\
\text { konsumpcji; }\end{array}$ \\
\hline Polityczne & $\begin{array}{l}\text { Rozszerzanie się demokracji, wzrost znaczenia podmiotów nie- } \\
\text { państwowych (np. „nowe ruchy społeczne”), wzrost populizmu, } \\
\text { rosnące „napięcia” między mocarstwami światowymi; }\end{array}$ \\
\hline Religijne & Sekularyzacja, indywidualizacja religijna, „nowa duchowość”; \\
\hline Edukacyjne & $\begin{array}{l}\text { Upowszechnienie szkolnictwa wyższego, obniżenie wieku rozpo- } \\
\text { częcia obowiązkowej edukacji szkolnej; }\end{array}$ \\
\hline Środowiskowe & $\begin{array}{l}\text { Wyczerpywanie się zasobów naturalnych, jałowienie gleby, } \\
\text { deforestacja, przekształcanie środowiska naturalnego, globalne } \\
\text { ocieplenie; }\end{array}$ \\
\hline Techniczne & $\begin{array}{l}\text { Zaawansowana technologia, cyfryzacja i digitalizacja, rozpo- } \\
\text { wszechnienie się Internetu, automatyzacja i robotyzacja produk- } \\
\text { cji, rozwój alternatywnych źródeł energii. }\end{array}$ \\
\hline
\end{tabular}

Źródło: Opracowanie własne na podstawie opracowań naukowych i raportów badawczych².

2 Np.: CSIRO. (2012). Our future world. Global megatrends that will change the way we live; Ernst\&Young. (2015). Megatrends. Making sense of a world in motion; Komisja Europejska. (2012). Global Europe 2050; Eurydice. (2012). Key Data on Education in Europe 2012. 
Opisane powyżej przykłady to tylko wybrana cząstka z bogatej palety potężnych trendów światowych, nagłaśnianych przez naukowców i raporty badawcze. W tekście uwzględniłem przede wszystkim zmiany globalne, istotne w kontekście Europy Zachodniej. Część tzw. procesów globalnych dotyka Europę wolniej, inne zaś stanowią przede wszystkim zagrożenie dla Starego Kontynentu, gdzie indziej (jeszcze?) nie docierając. W każdym z obszarów wyszczególnionych w powyższej tabeli można wskazać jeszcze inne tendencje o charakterze globalnym, które będą współkształtowały przyszły świat. Większych trudności nie przysparza wskazanie kolejnych obszarów życia człowieka, w których występują niewymienione w tabeli globalne tendencje. Powyższa klasyfikacja jest otwarta; zapewne w niedalekiej przyszłości pojawiać się będą kolejne zjawiska i procesy, których dotychczas jeszcze nie zdiagnozowano, a które generują już współczesna kultura, gospodarka, polityka. Im wcześniej zostaną rozpoznane, tym większe będą szanse na podjęcie efektywnych działań pomocnych w budowaniu przyjaznego człowiekowi świata. Problematyka megatrendowa, zainicjowana publikacją książki Johna Naisbitta (1997), zyskuje stale na znaczeniu jako coraz istotniejszy element myślenia o przyszłości. Powyższe rozważania rzucają światło jedynie na kilka trendów o charakterze globalnym, z których każdy zasługuje na osobne analizy. Wszystkie one niosą ze sobą liczne konsekwencji nie tylko dla światowych rynków, geopolitycznego porządku czy stanu środowiska naturalnego, lecz także dla codziennego życia jednostek. Skutki obserwowanych dziś trendów, ale także tych, których pojawienia można spodziewać się wkrótce, wiążą się z szansami, które świat może wykorzystać do urzeczywistnienia celów społecznie pożądanych. Z drugiej strony trzeba przygotować się na występowanie wielu zagrożeń i niebezpieczeństw. Lekkomyślność i brak odpowiedzialności współczesnych społeczeństw może przesądzić o tym, że przyszłość będzie mniej przyjazna człowiekowi, targana niekończącymi się konfliktami i napięciami. Jon Mandle (2009, s. 178) zauważa: „Jeśli zdamy sobie sprawę z różnorodności kultur, praktyk i wartości w dzisiejszym świecie oraz z historii obojętności i wrogości pomiędzy narodami, może się nam wydać, że proces globalizacji może zaowocować głębszą humanizacją. Nie odważę się na stwierdzenie, czy zbliżamy się czy oddalamy od tego celu, ale taka jest przynajmniej potencjalna ścieżka dla globalnej sprawiedliwości. Jeżeli [...] jest ona możliwa, ale nie nieunikniona, naszym obowiązkiem nie jest moralizowanie, ale skierowanie nas wszystkich na tę ścieżkę". Alternatywnych scenariuszy przyszłości jest wiele. Możliwie szybkie rozpoznanie „megatrendów” może wesprzeć strategów w konstruowaniu odpowiednich koncepcji, umożliwiających realizację optymistycznych wizji dalszego rozwoju. Oprócz tego konieczne są: „globalny” konsens co do priorytetów rozwojowych, dobre i skuteczne strategie, mądre decyzje polityczne na poziomie lokalnym i globalnym oraz zaangażowanie rządów i całych społeczeństw. 


\section{Zakończenie. W kierunku uczenia się przez całe życie}

Klamrę spinającą problematykę związaną z globalizacją stanowi edukacja globalna, która jest „najbardziej głośnym przyszłościowym wyzwaniem pedagogicznym, przezwyciężającym tradycyjnie dominującą perspektywę narodową czy państwową na rzecz zintegrowanego pokojowego współżycia ludzkości w perspektywie międzynarodowej i międzykontynentalnej" (Wołoszyn 1998, s. 145). Jedni rozumieją ją jako uniwersalny projekt moralno-etyczny, inni jako dźwignię zmiany społecznej, inni jeszcze jako podstawowy warunek urzeczywistnienia idei zrównoważonego rozwoju, edukację międzykulturową albo edukację na rzecz praw człowieka. Niemniej wszystkie nurty myślenia o edukacji globalnej akcentują ogólnoświatową, zbiorową współzależność. Nie sposób odnieść się w tym miejscu do różnorodnych koncepcji edukacji globalnej, oferowanych przez myślicieli i badaczy identyfikujących się z rozmaitymi światopoglądami i ideologiami, dlatego zwrócę uwagę na jedną tylko perspektywę, która wpisuje się we wszystkie nurty myślenia w kategoriach globalnych i co do której doniosłości istnieje pełen konsens. Jest nią uczenie się przez całe życie, stanowiące dotychczas bardziej koncepcję, wizję, postulat niż rzeczywistość. Głośnym echem odbiły się dokumenty: raport Faure’a Uczyć się, aby być (1975) i raport Delorsa Edukacja. Jest w niej ukryty skarb (1996), które stworzyły podwaliny do rozwoju nowoczesnych systemów edukacyjnych w państwach wysoko uprzemysłowionych, ukazując wartość i znaczenie edukacji towarzyszącej człowiekowi na każdym etapie życia. Mniejszą uwagę przykuwa raport UNESCO (2008) o uczeniu się i edukacji dorosłych ${ }^{3}$, który dowodzi, że systemy edukacyjne w licznych krajach świata nie są w stanie sprostać wyzwaniu, jakim jest zapewnienie wszystkim obywatelom dostępu do edukacji przez całe życie. Pokonanie różnorodnych barier ekonomicznych, politycznych, społecznych i strukturalnych, ograniczających udział dzieci, młodzieży i osób dorosłych w edukacji jest zresztą problemem nie tylko państw najuboższych. Tymczasem wyrównanie szans edukacyjnych stanowi „jeden z najważniejszych warunków przezwyciężenia niesprawiedliwości społecznej i ograniczania nierówności społecznych w każdym kraju (UNESCO 2008, s. 24) oraz rozwoju krytycznego myślenia i aktywnego, zaangażowanego obywatelstwa. Globalne „megatrendy” wymagają globalnej reakcji ze strony systemów oświatowych. Chodzi zarówno o holistyczne podejście do edukacji w ramach narodowych systemów edukacji, a zwłaszcza o postęp w opiece nad małym dzieckiem i w edukacji podstawowej, determinujących procesy uczenia się człowieka w późniejszych fazach życia, jak i międzynarodowe porozumienie w odniesieniu do konieczności poprawy dostępu do edukacji i podniesienia jej jakości. Chodzi zatem o jej otwartość dla wszystkich i ciągłość obejmującą całe ludzkie życie i wszelkie obszary uczenia się: uczenie się formalne, pozaformalne

3 Od 2009 roku ukazały się trzy kolejne raporty. Publikacja następnego jest przewidziana na rok 2019. 
i nieformalne. Uczenie się przez całe życie otwiera szansę na uczestnictwo społeczne, na działanie, na adekwatną reakcję na społeczne, polityczne, gospodarcze i kulturowe wyzwania. Znany socjolog Zygmunt Bauman (2007, s. 229) pisał, że jeśli „edukacja i uczenie się mają się do czegoś przydać to muszą mieć charakter ciągły i rzeczywiście trwać przez całe życie”. Wykorzystanie potencjału tkwiącego w całożyciowej edukacji jednostek i społeczeństw jest fundamentalnym warunkiem sprostania globalnej złożoności problemów nękających świat i urzeczywistnienia aspiracji do jego pokojowego zrównoważonego rozwoju, opartego na powszechnie akceptowanych wartościach i podstawowych prawach człowieka.

\section{Bibliografia}

Bauman Z. (2000). Globalizacja. Klekot E. (tłum.). Warszawa: Państwowy Instytut Wydawniczy.

Bauman Z. (2007). Szanse etyki w zglobalizowanym świecie. Konieczny J. (tłum.). Kraków: Wydawnictwo „Znak”.

BBVA (2016). European urbanization trends, dostępny na: https://www.bbvaresearch.com/wp-content/uploads/2016/12/European-urbanization-trends_.pdf (otwarto: 17.06.2018).

Benedykt XVI, Centre for Religion and Society. (2018). Europe's Young Adults and Religion, dostępny na: https://www.stmarys.ac.uk/research/centres/benedict-xvi/docs/2018-mar-europe-young-people-report-eng.pdf (otwarto: 6.07.2018).

Borodako K. (2009). Foresight w zarządzaniu strategicznym. Warszawa: C. H. Beck.

Cuhls K., Bunkowski A., Behlau L. (2012). Fraunhofer future markets: From global challenges to dedicated, technological, collaborative research projects. „Science and Public Policy", nr 39, s. 232-244.

CSIRO (2012). Our future world. Global megatrends that will change the way we live, dostępny na: https://publications.csiro.au/rpr/download?pid=csiro:EP1261 35\&dsid=DS2 (otwarto: 4.07.2018).

Czerniawska O. (2002). Starość wczoraj, dziś i jutro. W: Wnuk W (red.). Ludzie starsi $w$ trzecim tysiacleciu. Szanse-nadzieje-potrzeby. Wrocław: Uniwersytet Trzeciego Wieku w Uniwersytecie Wrocławskim.

Delors J. (1998). Edukacja. Jest w niej ukryty skarb. Rabczuk W. (tłum.). Warszawa: Stowarzyszenie Oświatowców Polskich.

Eurydice (2012). Key Data on Education in Europe 2012, dostępny na: http:// ec.europa.eu/eurostat/documents/3217494/5741409/978-92-9201-242-7-N.PDF/ dodcboda-5c52-4b33-becb-027fo5e1651f; link skrócony: http://bit.ly/fp2019-2-4 (otwarto: 5.07.2018)

Ernst\&Young (2015). Megatrends. Making sense of a world in motion, dostępny na: https://www.ey.com/Publication/vwLUAssets/ey-megatrends-report-2015/\%24FILE/ey-megatrends-report-2015.pdf (otwarto: 26.06.2018). 
Faure E. (1975). Uczyć się, aby być. Zakrzewska Z. (tłum.). Warszawa: Państwowe Wydawnictwo Naukowe.

Giddens A. (2012). Socjologia. Sulżycka A. (tłum.). Warszawa: Wydawnictwo Naukowe PWN.

Horx M. (2007). Macht der Megatrends, dostępny na: http://www.horx.com/Reden/ Macht-der-Megatrends.aspx (otwarto: 12.06.2018).

Komisja Europejska (2012). Global Europe 2050, dostępny na: https:/ec.europa.eu/ research/social-sciences/pdf/policy_reviews/global-europe-2050-report_en.pdf (otwarto: 1.07.2018).

Komitet Prognoz „Polska w XXI wieku” przy Prezydium PAN. (1995). W perspektywie roku 2010. Droga do roku 2010. Raport w sprawie opracowania długofalowej strategii rozwoju Polski na okres 15 lat. Warszawa: Dom Wydawniczy „Elipsa”.

Mandle J. (2009). Globalna sprawiedliwość. Dera M. (tłum.). Warszawa: Wydawnictwo Sic!

Mariański J. (2016). Megatrendy religijne w społeczeństwach ponowoczesnych. Studium Socjologiczne. Toruń: Wydawnictwo Adam Marszałek.

Mayor F. (2001). Przyszłość świata. Wolf J., Janik A., Rabczuk W. (tłum.). Warszawa: Fundacja Studiów i Badań Edukacyjnych.

Muszyński J. (2001). Megatrendy a polityka. Wrocław: ATLA 2.

Naisbitt J. (1997). Megatrendy. Dziesięć nowych kierunków zmieniających nasze $\dot{z} y c i e$. Kwiatkowski P. (tłum.). Poznań: Zysk i S-ka.

Nowakowska-Siuta R., Śliwerski B. (2015). Racjonalność procesu kształcenia: studium z polityki oświatowej i pedagogiki porównawczej. T. 1. Kraków: Oficyna Wydawnicza „Impuls”.

ONZ (2018). Revision of World Urbanization Prospects, dostępny na: https:// esa.un.org/unpd/wup/Publications/Files/WUP2018-KeyFacts.pdf (otwarto: 5.07.2018).

Pajestka J. (1994). O orientację na przyszłość w reformach polskich. Megatrendy cywilizacyjne a procesy transformacji systemowej. Warszawa: Dom Wydawniczy „Elipsa”.

Penn M., Zalesne E. K. (2007). Microtrends: the small forces behind tomorrow's big changes. Nowy Jork: Hachette Book Group.

Piketty T. (2015). Ekonomia nierówności. Bilik A. (tłum.). Warszawa: Wydawnictwo Krytyki Politycznej.

Prandecki K. (2012). Rola megatrendów w przewidywaniu przyszłości. „Przyszłość. Świat-Europa-Polska", nr 2, s. 75-94.

Paprocki W., Pieriegud J. (2015). Megatrendy i ich wpływ na rozwój sektorów Infrastrukturalnych. Gdańsk: Instytut Badań nad Gospodarką Rynkową Gdańska Akademia Bankowa.

Sumlicka M. (2016). Trendy we współczesnej gospodarce światowej a globalny biznes. W: Stacewicz J. (red.). Polityka gospodarcza w warunkach przemian rozwojowych. Warszawa: Oficyna Wydawnicza Szkoła Główna Handlowa. 
Stiglitz J. (2015). Cena nierówności. W jaki sposób dzisiejsze podziały społeczne zagrażaja naszej przyszłości. Mitoraj R. (tłum.). Warszawa: Wydawnictwo Krytyki Politycznej.

Śliwerski B. (2018). Czy jest jeszcze potrzebna pedagogika porównawcza? W: Nowakowska-Siuta R., Dmitruk-Sierocińska K. (red.). Polityka oświatowa w perspektywie porównawczej. Kraków: Oficyna Wydawnicza „Impuls”.

UNESCO. (2008). EFA Global Monitoring Report 2009: Overcoming inequality: why governance matters. Oxford, Paris: Oxford University Press, UNESCO Publishing.

UNESCO. (2009). Global Report on Adult Learning and Education. Hamburg UNESCO Institute for Lifelong Learning.

Walzer H. (2016). Samodzielne myślenie. Grotowicz W. (tłum.). Słupsk: Wydawnictwo Dobra Literatura - Grupa Wydawnicza „Literatura Inspiruje”.

Wołoszyn S. (1998). Nauki o wychowaniu w Polsce w XX wieku. Próba syntetycznego zarysu na tle powszechnym. Kielce: Dom Wydawniczy „Strzelec”.

Zacher L. W. (2003). Spór o globalizację. Eseje o przyszłości świata. Warszawa: Dom Wydawniczy „Elipsa”.

\title{
MEGATRENDS IN THE CONTEMPORARY WORLD: EUROPEAN PERSPECTIVE
}

\begin{abstract}
In the article, the author raises the issue of "megatrends", that is essential and principal tendencies of global range. He briefly characterizes this notion, the meaning of which has evolved over the years, and presents its major features. The author emphasizes the controversies about calling specific phenomena "megatrends". Identification of the forces that change the direction of the world development is one of the basic tools for predicting the future. Not only do they impact the lives of entire societies but also determine the composition of individual biographies. The article mentions the most important research-based tendencies visible in the contemporary world. The author reviews them from the European perspective and outlines the major challenges for the Western world. In the pedagogical context, he emphasizes the importance of lifelong learning as a key to solving global and educational problems and challenges.
\end{abstract}

Keywords: megatrends; globalization; urbanization; demography; education.

Błażej Przybylski - doktor nauk społecznych w zakresie pedagogiki; adiunkt w Instytucie Pedagogiki w Akademii Pedagogiki Specjalnej im. Marii Grzegorzewskiej w Warszawie. Jego zainteresowania naukowe i badawcze oscylują wokół problematyki młodzieży, jej poglądów, aktywności, aspiracji oraz społecznych uwarunkowań kształcenia. Adres korespondencyjny: Akademia Pedagogiki Specjalnej im. Marii Grzegorzewskiej, ul. Szczęśliwicka 40, 02-353 Warszawa. Adres e-mailowy: blazej.przybylski@wp.pl. 